Article

\title{
Assessment of the Use of Potatoes as a Binder in Flax Heating Pellets
}

\author{
Jiři Souček ${ }^{1}$ and Algirdas Jasinskas ${ }^{2, *}$ \\ 1 Research Institute of Agricultural Engineering, 16101 Prague 6, Czech Republic; jiri.soucek@vuzt.cz \\ 2 Institute of Agricultural Engineering and Safety, Agriculture Academy, Vytautas Magnus University, \\ Akademija, LT-53362 Kaunas Distr., Lithuania \\ * Correspondence: algirdas.jasinskas@vdu.lt; Tel.: +370-612-04002
}

Received: 27 November 2020; Accepted: 13 December 2020; Published: 15 December 2020

\begin{abstract}
This article focuses on an examination of the possibility of using potatoes as a binder in the production of heating pellets from flax stalks. This research was carried out in the form of an experimental production, laboratory analyses, and combustion tests of pellets with the Biltstar variety of flax stalks. The production was carried out using an MGL 200 pelletizing line. Adéla potatoes were used as a binder at a dose of $10 \%$. The results were compared to the control variant without the addition of potatoes. Potatoes had a positive effect on the mechanical properties of the pellets as well as on carbon monoxide emissions. A positive effect of the addition of potatoes was recorded by an increase in specific weight $\left(599.2 \mathrm{~kg} / \mathrm{m}^{3}\right.$ for the potato-free variant and $1092.3 \mathrm{~kg} / \mathrm{m}^{3}$ for the variant with potatoes) and a significant increase in mechanical durability $(4.39 \%$ for the potato-free variant and $0.71 \%$ for the variant with potatoes). The biggest difference was measured in carbon monoxide emissions $\left(13,082 \mathrm{mg} / \mathrm{m}^{3}{ }_{\mathrm{N}}\right.$ for the potato-free $\mathrm{mg} / \mathrm{m}^{3}{ }_{\mathrm{N}}$ ariant and $5186 \mathrm{mg} / \mathrm{m}^{3}{ }_{\mathrm{N}}$ for the variant with potatoes). The values were converted to a reference oxygen content of $10 \%$.
\end{abstract}

Keywords: biofuels; bioenergy; pellets; potatoes; durability; emission; combustion; flax; linseed

\section{Introduction}

Agricultural production is a basic source of organic products. While priority is given to the production of food for human consumption, a significant part of the production is raw materials that are used for technical purposes. Recently, agriculture has become an important source of raw materials for energy. The demand for green energy and biomass-based fuels is increasing. From an environmental and social point of view, the use of residual biomass is especially desirable. Given that its further use in agriculture is problematic or undesirable [1], it is increasingly more used for the production of fuel.

An example of such raw material is flax stalks. In the production of pressed biofuels from flax, it is difficult to achieve the required properties, especially mechanical ones (e.g., specific weight, mechanical durability, and uniformity of dimensions) [2,3]. Incorporation of a flax stalk into the soil often poses a problem for subsequent tillage. According to reference [4], undecomposed fiber parts commonly cause clogging of the working organs of pre-sowing preparations and sowing machines. Moreover, incorporated stalk residues are often a source of pests.

The demand for flax is declining worldwide. However, the literature describes alternative and newly developed ways of using it. For example, some authors have achieved good results using flax as part of composites $[5,6]$. These are interesting and progressive methods of use. Unfortunately, they do not yet have the potential to use flax stalks to the required extent. Therefore, its use for energy seems like a promising option. 
Due to the long-term unfavorable situation on the vegetable fiber market, it is ideal to use flax stalks to produce biofuels. However, the disadvantage from this point of view, according to reference [7], is the physical properties of the stem, which, in addition to lumps, contains a high proportion of fibers that are very flexible and difficult to compress. When compressed, enhanced increased elasticity causes partial loosening of the material and poor durability of the final product.

The proposed solution suggests adding suitable additives that will improve the mechanical and fuel energy properties of the final product [8]. The utilization of additives that do not impose significant technological and economic requirements for their acquisition is particularly advantageous. The mechanical properties of the final product can be improved by adding suitable raw materials to the molding compound. For example, Polish researchers [9] verified the possibilities of using apple waste.

According to reference [10], one of the solutions is adding dry coniferous wood in the form of sawdust or shavings. The addition of wood improves the properties of the final product. Unfortunately, it is not always enough to meet the mechanical properties required by the standards. Processing a larger number of flax stalks can present a logistical problem in terms of securing and storing the required amount of suitable wood. This can have a significant impact on production costs [11].

The work of some authors [12] shows that starch is a suitable binder for solid biofuels. Starch is an important raw material for gluing. It is used as a part of adhesives and is an adhesive itself that dissolves in moisture. Additionally, the possibilities of using low-quality flour or bran $[13,14]$ are known from practice. However, the possibility of using potatoes as an additive in the production of pellets from oil flax stalks has not been described in the literature.

The idea of using potatoes as a biofuel is based on the nature of potatoes as a raw material rich in starch. The issue of the use of energy from potatoes has been addressed by several authors [15-17] in terms of its use for biogas production. Other authors $[18,19]$ have described the possibility of using potatoes as a solid biofuel as problematic. Regarding the use of potato waste, the production of pellets from potato peel has been described in the literature [20]. According to reference [21], the use of potato pulp as part of pressed biofuels is a suitable solution, especially for the use of overproduced potatoes. However, no information can be found in the literature on experiments with the addition of whole disintegrated potatoes as a binder for the heating pellets from flax stalks.

In addition to mechanical properties, the properties of heating pellets in terms of energy and fuel are important, especially high heating value (HHV), low heating value (LHV), and moisture content [22]. From a qualitative point of view, understanding the analytical composition [23] is necessary.

In fuel testing, this is a way to determine the amount of emissions from fuel combustion [24]. These are mainly emissions of carbon monoxide, carbon dioxide, and nitrogen oxide $\left(\mathrm{NO}_{\mathrm{x}}\right)$. The results of combustion tests and the determination of harmful emissions have been published in the works of researchers in many countries [25-28]. The possibility of pelleting post-harvest tobacco residues and pellets and comparing the combustion properties to wood pellets has been investigated by reference [29].

The aim of this work was to evaluate the influence of the use of potatoes as a binder in the production of pellets from residual flax stalks on their mechanical and fuel energy properties. The goal was to expand the possibilities of using flax stalks and potatoes in the field of energy, as this would create better conditions for their cultivation and stabilization of production on the market. From an energy point of view, the aim was to verify the possibilities of expanding the biofuels' portfolio and, thus, to contribute to increasing the share of renewable sources of energy.

\section{Materials and Methods}

The aim of the research was to determine the influence of the addition of potatoes on the properties of heating pellets produced from flax stalks. For this purpose, 10 batches of flax stalk pellets without added potatoes and 10 batches of flax stalk pellets with added potatoes were produced. One batch consisted of approximately $50 \mathrm{~kg}$ of pellets. Both variants of the pellets were compared in terms of their production parameters and in terms of their mechanical and energy properties. 
The stalks of the Biltstar flax oil variety were used for the experimental production of pellets. The flax stalks obtained from large straw bales were shredded using a cutting shredder RS 650 (Kovo Novák, Czech Republic) with an installed sieve with holes of $8 \mathrm{~mm}$ in diameter. Batches of raw material were inserted manually. The average particle length of the used biomass crumb was $12.3 \pm 4.49 \mathrm{~mm}$. The device parameters can be found in Table 1 [30].

Table 1. KovoNovák RS 650 parameters.

\begin{tabular}{cc}
\hline Parameter & Value \\
\hline Power consumption & $5.50 \mathrm{~kW}$ \\
Input voltage & $400 \mathrm{~V} / 25 \mathrm{~A}$ \\
Weight & $185 \mathrm{~kg}$ \\
Dosing hole diameter & $76 \mathrm{~mm}$ \\
Shredding performance (4 mm sieve) & $300-600 \mathrm{~kg} / \mathrm{h}$ \\
\hline
\end{tabular}

Potatoes of the Adéla variety (Selekta Pacov, a.s., Czech Republic) were used as binders in the pressing mixture. This is an early variety of starch potatoes intended for technical use. It is highly resistant to viral diseases and potato blight (Ro1) and achieves a high yield of oval tubers with a deep yellow flesh that are resistant to mechanical damage and general scab. Moreover, it is suitable for storage and consumption all year round [31].

A Retsch SM 300 (Retsch GmbH, Germany) [32] shearing mill was used to prepare the potatoes. The particle size of the crushed potatoes ranged from 2 to $4 \mathrm{~mm}$. Potatoes, including their skins, were crushed and washed to remove unwanted impurities. The starch content in the potatoes was $12.3 \%$ and the nitrogen content was $0.93 \%$.

Compressed flax stalk mixtures were prepared from the crushed material by homogenization. Potatoes were added, $10 \%$ by weight, to the mixture. The homogenized mixtures were used for the production of pellets on the MGL 200 (Kovo Novák, Czech Republic) production line, which was equipped with a dosing worm conveyor, a compounder, a horizontal matrix granulation press, and a rotary screen cooler (sorting apparatus). The press was equipped with two rollers and a rotating matrix. The diameter of the press holes was $6 \mathrm{~mm}$ and the length (matrix thickness) was $30 \mathrm{~mm}$. The main operating parameters of the whole line provided by the manufacturer are shown in Table 2, and its scheme is presented in Figure 1 [33].

Table 2. Kovo Novák MGL 200 parameters.

\begin{tabular}{cc}
\hline Parameter & Value \\
\hline Power consumption & $8.85-10.85 \mathrm{~kW}$ \\
Input voltage & $400 \mathrm{~V} / 25 \mathrm{~A}$ \\
Performance of wooden pellets & $50-100 \mathrm{~kg} / \mathrm{h}$ \\
Performance of bio pellets & $50-150 \mathrm{~kg} / \mathrm{h}$ \\
\hline
\end{tabular}

The following parameters were measured during all the operations with the abovementioned machines: electric energy consumption, operating time, and total weight of the final products. A programmable electrical power and energy analyzer, PROWATT-3, Chauvin Arnoux, was used to measure the energy consumption. The weight was determined using KERN FKB-30K1A balance (with the weighing capacity of $30 \mathrm{~kg}$ and the error of $20 \mathrm{~g}$ ) [34]. The values of these indicators per unit of production were calculated based on the obtained data (i.e., specific electricity consumption and efficiency). 


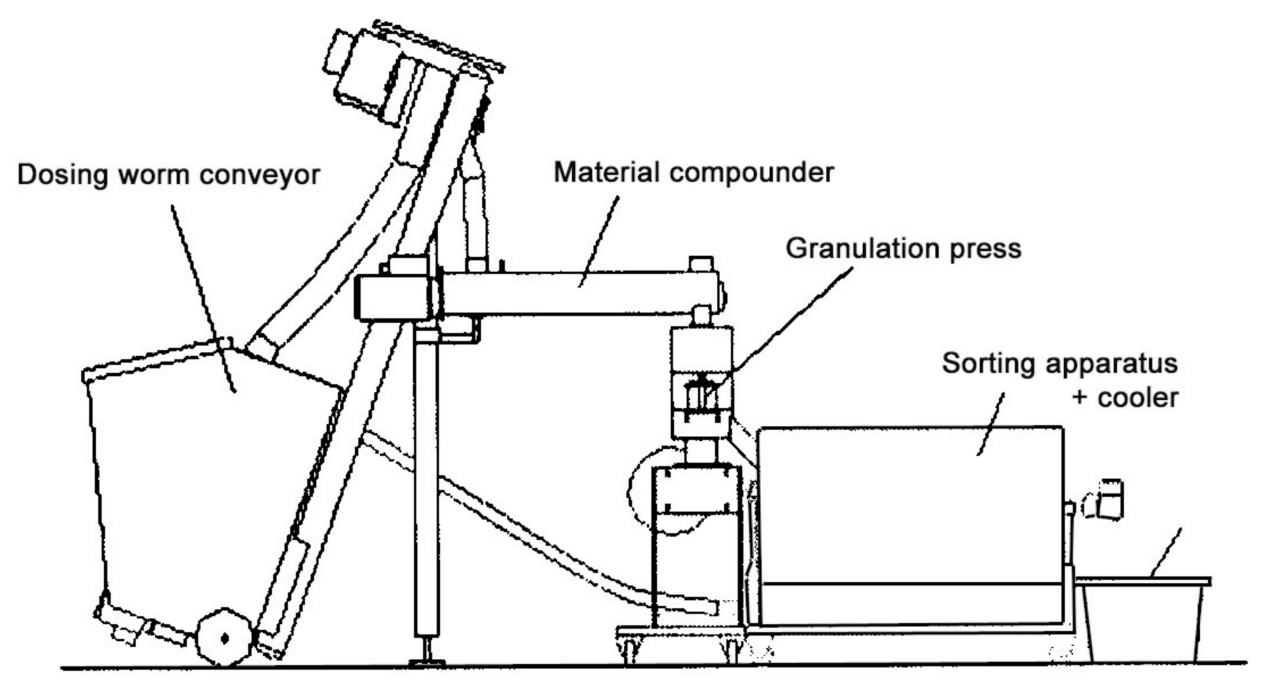

Figure 1. MGL 200 scheme.

The following parameters were monitored and calculated: total weight of the pellets produced, electricity consumption, one-hour capacity of the line, specific electricity consumption, combustion heat and heating value of pellets, and mechanical durability and moisture content of the pellets. Additionally, the following parameters were determined in the laboratory for the final products:

- $\quad$ Specific weight (about EN 15150:2011) [35];

- Mechanical durability (about ISO 17831-1: 2015) [36];

- Moisture content (about ISO 18134-3:2015) [37];

- Calorific value and combustion heat (about ISO 18125:2018) [38];

- $\quad$ Analytical composition (about EN 15297:2011, ISO 16948:2015) [39,40].

A KERN 572 Max. (weighing capacity $3030 \mathrm{~g}$ and error $0.01 \mathrm{~g}$ ) laboratory balance was used to measure the weight in the determination of dry matter, specific weight, and durability. A KERN PNS (weighing capacity $620 \mathrm{~g}$ and error $0.001 \mathrm{~g}$ ) analytical laboratory balance was used for analytical analysis. The durability was determined as well. The FD-S 115 Solid Line drying binder with a volume of $115 \mathrm{~L}$ was used to dry the samples. An IKA C 6000 calorimeter was used to determine the heat combustion. A LECO CHN 628 analyzer was used for analysis of the content of carbon, nitrogen, and hydrogen. An AMA 254, Altec Praha analyzer was used for analysis of the mercury content. The flame atomic absorption spectrometry (AAS) method (AAS GBC) was also used for the analysis of the elements. A regulator $\mathrm{Ht}$ Industry laboratory oven was used to determine the ash content.

Emissions of carbon monoxide, nitrogen oxide $\left(\mathrm{NO}_{\mathrm{x}}\right)$, and carbon dioxide from the combustion of the produced pellets were measured in a hot air boiler with a KNP 3 (Kovo Novák, Czech Republic). The boiler was equipped with an automatic burner that had an output of $9.5 \mathrm{~kW}$. The combustion plant was equipped with a fixed burner that had a top screw fuel supply. The device included a flue gas exhaust fan with adjustable speed. The emissions were measured in the fume duct with Testo 350xl device (TESTO GmbH, Germany) and counted over to a referential oxygen content of $10 \%$. During the tests, the amount of oxygen in the flue gas and the flue gas temperature were measured.

The values were converted to the reference oxygen content according to the formula:

$$
C_{r e f}=C_{\text {mea }} \frac{21-O_{r e f}}{21-O_{\text {mea }}}\left(\mathrm{mg} / \mathrm{m}^{3} \mathrm{~N}\right)
$$

where $C_{r e f}$ is the referential concentration $\left(\mathrm{mg} / \mathrm{m}^{3} \mathrm{~N}\right), C_{\text {mea }}$ is the concentration measured $\left(\mathrm{mg} / \mathrm{m}^{3} \mathrm{~N}\right)$, $O_{r e f}$ is the referential amount of oxygen (\%), $O_{\text {mea }}$ is the measured amount of oxygen (\%). 
The properties of the pellets that were important from the research point of view were selected based on ISO 17225-6: 2014 standard [41]. Statistical analysis was carried out using the software package "Statistica 12.0" (StatSoftInc., Tulsa, OK, USA). Analysis of variance was performed and the results were compared using Tukey's multiple range test $(\alpha=0.05)$.

Production of pellets, determination of their properties, and the combustion tests took place in the laboratories of the Research Institute of Agricultural Engineering, p. r. i. and the analytical tests were performed by an accredited laboratory.

\section{Results and Discussion}

\subsection{Energy Consumption and Production Efficiency}

The flax stalks were crushed in the same way for both variants using an RS 650 shredder with an $8 \mathrm{~mm}$ diameter sieve. The specific energy consumption of the crushing was $0.194 \mathrm{MJ} / \mathrm{kg}$ with an efficiency of $101.3 \pm 8.29 \mathrm{~kg} / \mathrm{h}$. The calorific value of the crushed stalks was $18.2 \mathrm{MJ} / \mathrm{kg}$ and the moisture content was $10.8 \%$. The specific energy consumption of the potato crushing was $0.05 \mathrm{MJ} / \mathrm{kg}$.

The specific energy consumption and the performance of the MGL 200 pressing line when pressing the pellets were different for the tested variants. The difference in performance was caused by a larger number of fractions and debris in the output of the press. They fell through the cooler sieve and were not part of the final product. The specific energy consumption ranged from 0.089 to $0.125 \mathrm{MJ} / \mathrm{kg}$ when only flax stalks without potatoes were pressed. The efficiency of the line when pressing the stalks without potatoes was $123 \pm 15 \mathrm{~kg} / \mathrm{h}$. Meanwhile, when pressing the flax stalks with the addition of potatoes, the specific energy consumption ranged from 0.078 to $0.106 \mathrm{MJ} / \mathrm{kg}$ and the efficiency value increased to $146 \pm 12 \mathrm{~kg} / \mathrm{h}$. The values for the individual variants are graphically presented in Figure 2 .

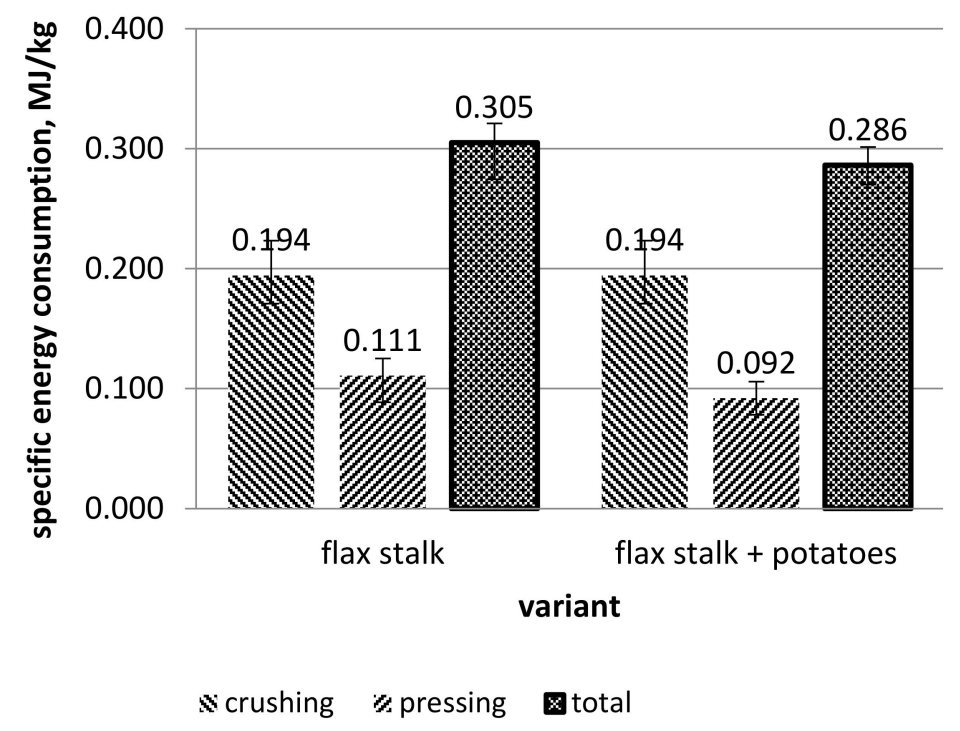

Figure 2. Specific energy consumption when testing the crushed and pressed pellet variants.

The specific energy consumption to produce both variants was similar $(0.305$ and $0.286 \mathrm{MJ} / \mathrm{kg})$ and within the range reported in the literature [1,3,21] (from 0.148 to $0.327 \mathrm{MJ} / \mathrm{kg}$ ). The indicated values of efficiency are comparable with the results in references $[1,3]$, where measurements were performed on the same type of lines. The measured performance values were lower than the reference values provided by the manufacturer [7]. However, these values are given for the production of wood sawdust pellets, for which the line is primarily designed. 


\subsection{Selected Mechanical Properties}

Differences between the observed variants were also recorded in terms of mechanical properties. Higher values of specific weight (by $1092.28 \mathrm{~kg} / \mathrm{m}^{3}$ ) and better durability (by $0.714 \%$ ) were recorded in the variant with the addition of potatoes. The specific weight of the potato-free variant was $599.17 \mathrm{~kg} / \mathrm{m}^{3}$ and the durability was $4.39 \%$. The values of the specific weight and durability are graphically shown in Figures 3 and 4.

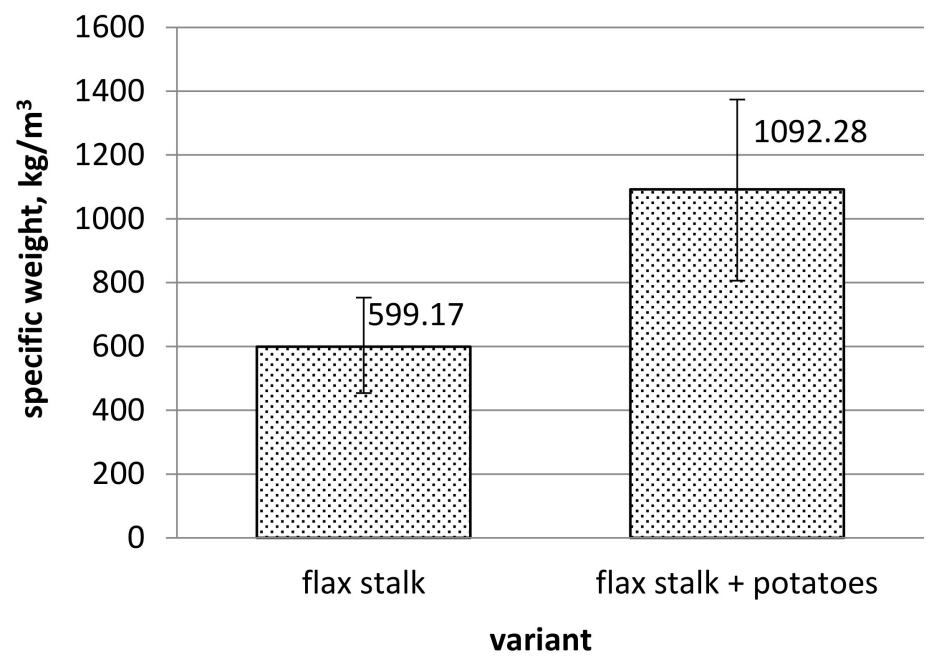

Figure 3. Specific weight of the pellet variants tested.

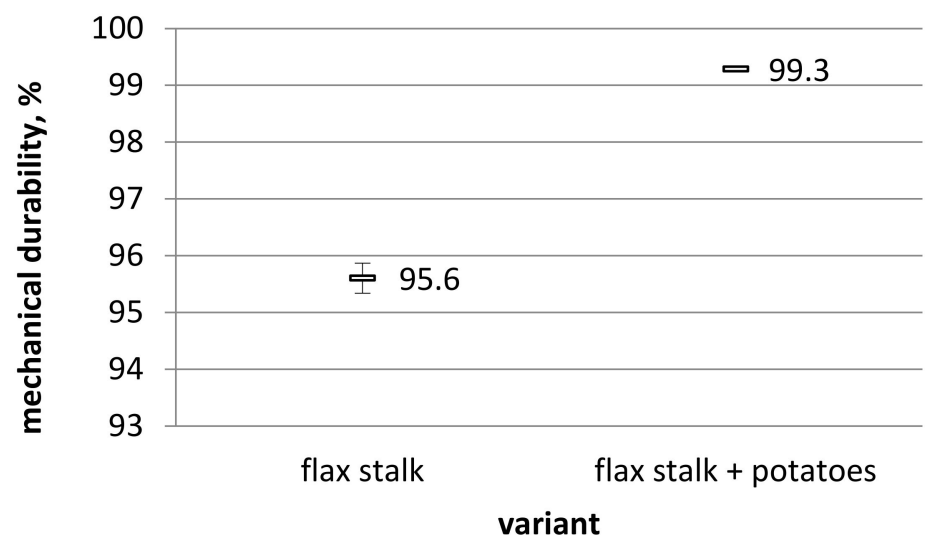

Figure 4. Mechanical durability of the pellet variants tested.

\subsection{Analytical Properties of the Produced Pellets}

The specific weight of the pellets with the addition of potatoes increased by an average of $82 \%$. The durability was reduced to $0.714 \%$, which is in line with the conditions of the standard for the properties of non-wood pellets [40]. The variance of the measured values also decreased significantly. Both results show that this indicator improved and stabilized with the addition of potatoes. Compared to the results of Soucek et al. [1], which focused on the pressing of pellets with the addition of sawdust, the durability was $3-5 \%$ lower. The specific weight of the pellets with the addition of sawdust ranged from 1150 to $1200 \mathrm{~kg} / \mathrm{m}^{3}$ and, therefore, was approximately $100 \mathrm{~kg} / \mathrm{m}^{3}$ higher [2]. However, the specific weight of the pellets obtained by adding the potatoes meets the conditions of the standard [40]. Comparable values were also achieved for pellets pressed from post-harvest tobacco residues $\left(1060-1260 \mathrm{~kg} / \mathrm{m}^{3}\right)$ [24].

The produced biofuel samples were analyzed in a laboratory, and the analytical composition of both variants is presented in Table 3. 
Table 3. Analytical composition of the pellet variants tested.

\begin{tabular}{ccc}
\hline \multirow{2}{*}{ Parameters } & \multicolumn{2}{c}{ Value, \% } \\
\cline { 2 - 3 } & Flax Stalk & Flax Stalk + Potatoes \\
\hline $\mathrm{C}, \%$ & $43.55 \pm 1.12$ & $43.36 \pm 1.14$ \\
$\mathrm{H}, \%$ & $5.34 \pm 0.45$ & $5.36 \pm 0.42$ \\
$\mathrm{O}, \%$ & $38.69 \pm 0.91$ & $38.85 \pm 0.90$ \\
$\mathrm{~S}, \%$ & $0.09 \pm 0.001$ & $0.11 \pm 0.001$ \\
$\mathrm{~N}, \%$ & $<0.1$ & $<0.1$ \\
$\mathrm{CI}, \%$ & $0.050 \pm 0.004$ & $0.051 \pm 0.004$ \\
$\mathrm{Si}, \%$ & $0.045 \pm 0.003$ & $0.049 \pm 0.004$ \\
$\mathrm{Ca}, \%$ & $0.375 \pm 0.025$ & $0.329 \pm 0.027$ \\
$\mathrm{Mg}, \%$ & $0.035 \pm 0.002$ & $0.036 \pm 0.003$ \\
$\mathrm{Na}, \%$ & $0.015 \pm 0.001$ & $0.017 \pm 0.002$ \\
$\mathrm{~K}, \%$ & $0.343 \pm 0.016$ & $0.321 \pm 0.020$ \\
$\mathrm{P}, \%$ & $0.051 \pm 0.004$ & $0.058 \pm 0.006$ \\
$\mathrm{Zn}, \mathrm{mg} / \mathrm{kg}$ & $11.3 \pm 0.75$ & $14.8 \pm 0.96$ \\
$\mathrm{Cd}, \mathrm{mg} / \mathrm{kg}$ & $<0.2$ & $<0.2$ \\
$\mathrm{Cr}, \mathrm{mg} / \mathrm{kg}$ & $<0.5$ & $<0.5$ \\
$\mathrm{Cu}, \mathrm{mg} / \mathrm{kg}$ & $5.4 \pm 0.096$ & $6.2 \pm 0.102$ \\
$\mathrm{As}, \mathrm{mg} / \mathrm{kg}$ & $<0.5$ & $<0.5$ \\
$\mathrm{Hg}, \mathrm{mg} / \mathrm{kg}$ & $0.0067 \pm 0.0004$ & $0.0060 \pm 0.0005$ \\
$\mathrm{Ash} \mathrm{content, \%}$ & $2.90 \pm 0.06$ & $3.05 \pm 0.18$ \\
\hline & &
\end{tabular}

It is clear from Table 3 that the two pellet variants produced are very similar. The only small differences would be in the content of ash, silicon, nitrogen, and zinc, due to the addition of potatoes with a small proportion of impurities.

High heating values (HHVs), moisture content, and low heating values (LHVs) were determined for the produced pellets. High heating values were similar in both variants, ranging from 18.17 to $18.26 \mathrm{MJ} / \mathrm{kg}$. The variant of pellets with the addition of potatoes had a slight increase in moisture content $(8.43 \%)$ in comparison to the variant without potatoes $(8.10 \%)$. This is also related to the low heating value, which is slightly lower in the variant with potatoes $(15.34 \mathrm{MJ} / \mathrm{kg})$ than in the variant without potatoes $(15.49 \mathrm{MJ} / \mathrm{kg})$. These values are in line with the results in reference [42], in which the experimental production of a mixture of straw and wood was carried out, reaching a low heating value from 17.3 to $20.1 \mathrm{MJ} / \mathrm{kg}$. High heating values, moisture content, and low heating values are shown graphically in Figure 5.

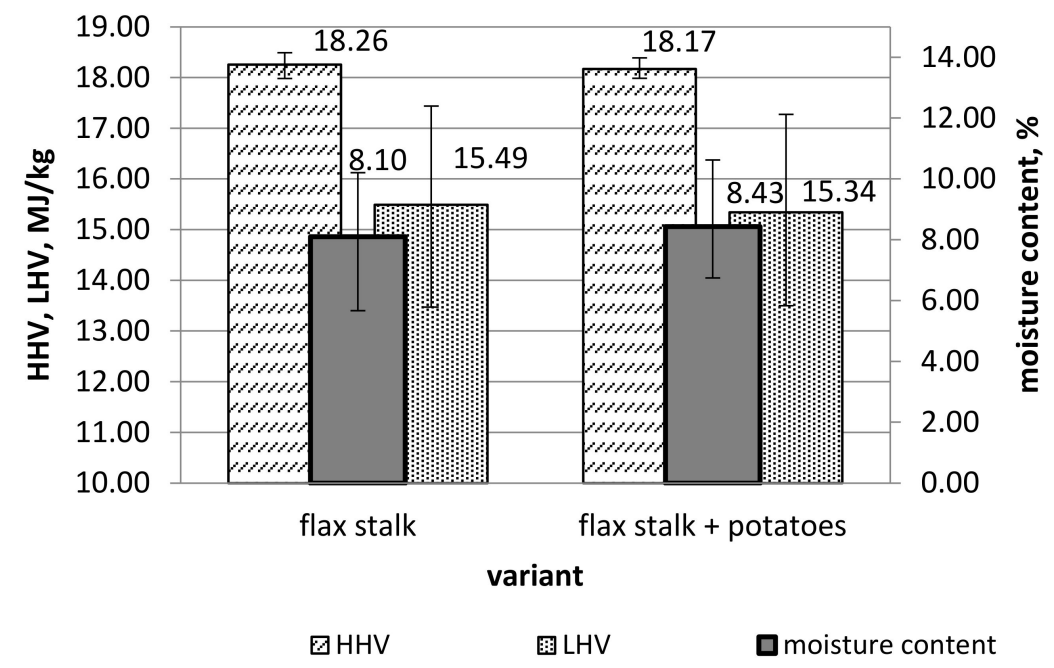

Figure 5. High heating values (HHVs), moisture content, and low heating values (LHVs) of the pellet variants tested. 
It is clear from the given values that the analytical and energy properties of the pellets produced are similar. Compared to the literature $[1,19,24]$, the values do not differ significantly. The high heating value corresponds to standard solid biofuels produced from plant biomass made from wood or herb stems. Due to a similar amount of hydrogen, the low heating value depends mainly on the moisture content.

\subsection{Combustion Tests and Measurement of Emissions}

As part of the combustion tests, the emissions arising from the combustion were determined for the different pellet variants. The largest difference was found in carbon monoxide emissions (Figure 6). For pellets without added potatoes, the average emission value was $13,082.16 \mathrm{mg} / \mathrm{m}^{3} \mathrm{~N}$ and the range was very wide-from 2787.41 to $57,560.75 \mathrm{mg} / \mathrm{m}^{3} \mathrm{~N}$. The average value of the pellets with potatoes was found to be $5186.07 \mathrm{mg} / \mathrm{m}^{3}{ }_{\mathrm{N}}$ and all values ranged from 1024.26 to $12,644.79 \mathrm{mg} / \mathrm{m}^{3}{ }_{\mathrm{N}}$.

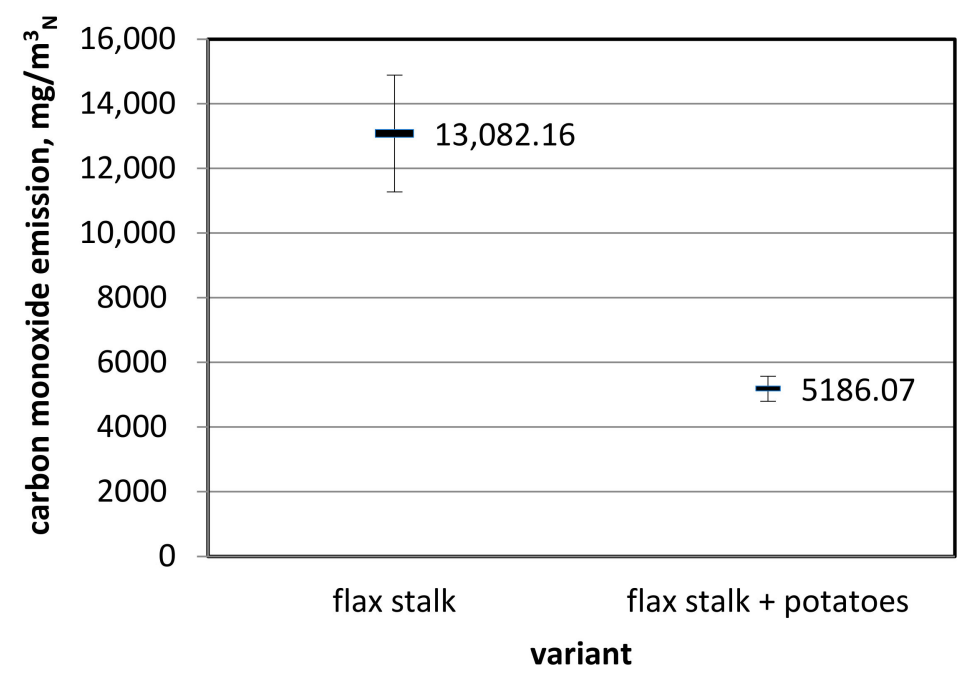

Figure 6. Average carbon monoxide emissions from the pellet variants tested.

It is clear from the graph in Figure 7 that higher carbon monoxide emissions of the potato-free variant were caused by poor combustion stability, especially in the first part of the combustion test. Throughout the test, the burning of the pellets with the addition of potatoes was even with only small fluctuations.

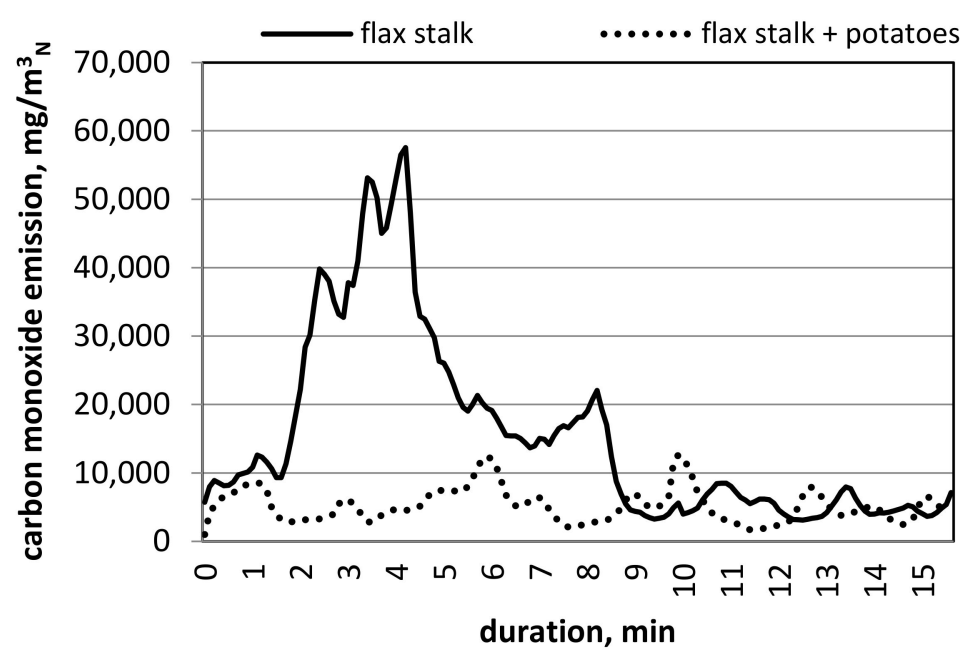

Figure 7. Duration of the carbon monoxide emissions from the pellet variants tested during the combustion test. 
The occurrence of the same problems has also been described by other authors [2,28], who investigated the combustion of imperfectly compressed materials. When burning in batches, the non-uniformity of the combustion with an abrupt increase in carbon monoxide emissions typically occurred in the case of briquettes from stalked materials [7].

The $\mathrm{NO}_{\mathrm{X}}$ emissions (Figure 8 ) are similar in both variants. The average value of the potato-free variant was $559.46 \mathrm{mg} / \mathrm{m}^{3} \mathrm{~N}$, while for the variant with potatoes, a slightly increased value was measured $\left(567.83 \mathrm{mg} / \mathrm{m}^{3} \mathrm{~N}\right)$; however, a narrower range of measured values was recorded for the latter, indicating a more stable course of the combustion process. The values determined can be seen in Figure 9.

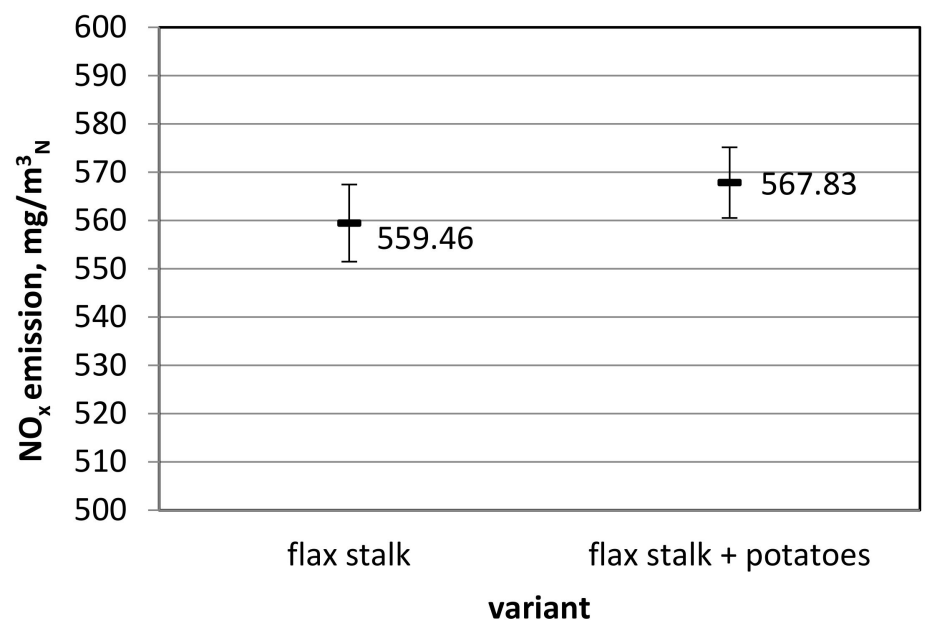

Figure 8. Average nitrogen oxide $\left(\mathrm{NO}_{\mathrm{x}}\right)$ emissions of the pellet variants tested.

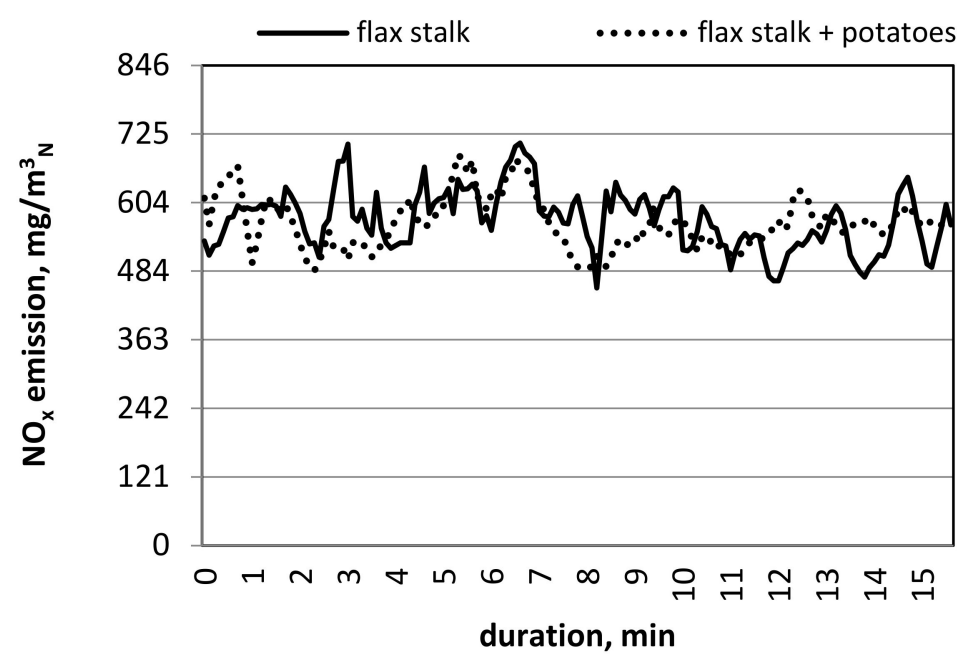

Figure 9. Duration of the $\mathrm{NO}_{\mathrm{x}}$ emissions of the pellet variants tested during the combustion test.

The carbon dioxide emissions (Figure 10) also did not show a significant difference in average values ( $1.81 \%$ for the variant without potatoes and $1.87 \%$ for the variant with potatoes). As in the case of $\mathrm{NO}_{\mathrm{x}}$ emissions, the range of measured values was narrower for the latter, which supports the assumption of a better combustion process stability for the potato variant. Graphical representation of the emission concentrations during the combustion test (Figure 11) shows an evident decrease in carbon dioxide emissions concentration in the first half of the test, which corresponds to an increase in the concentration of carbon monoxide emissions. 


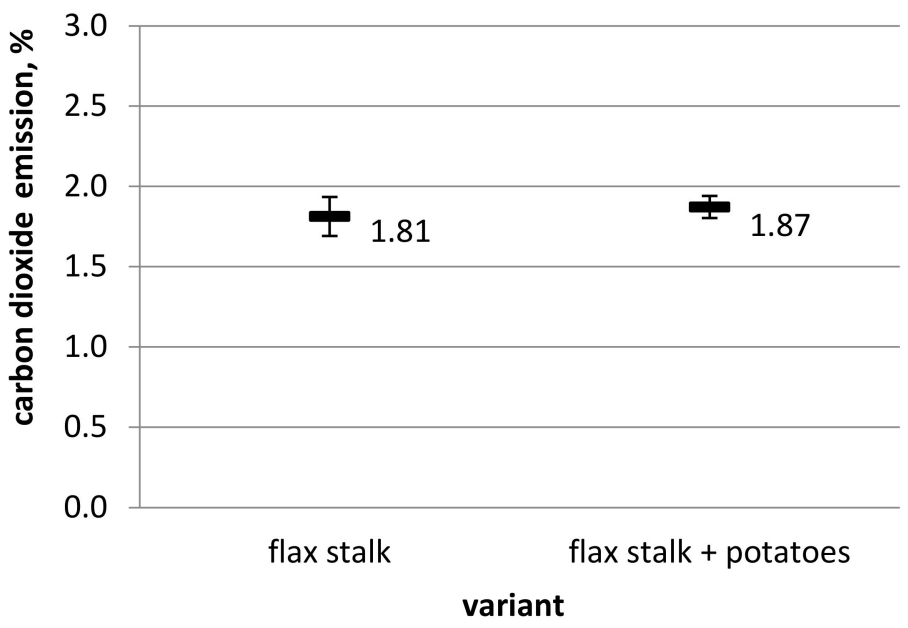

Figure 10. Average carbon dioxide emissions of the pellet variants tested.

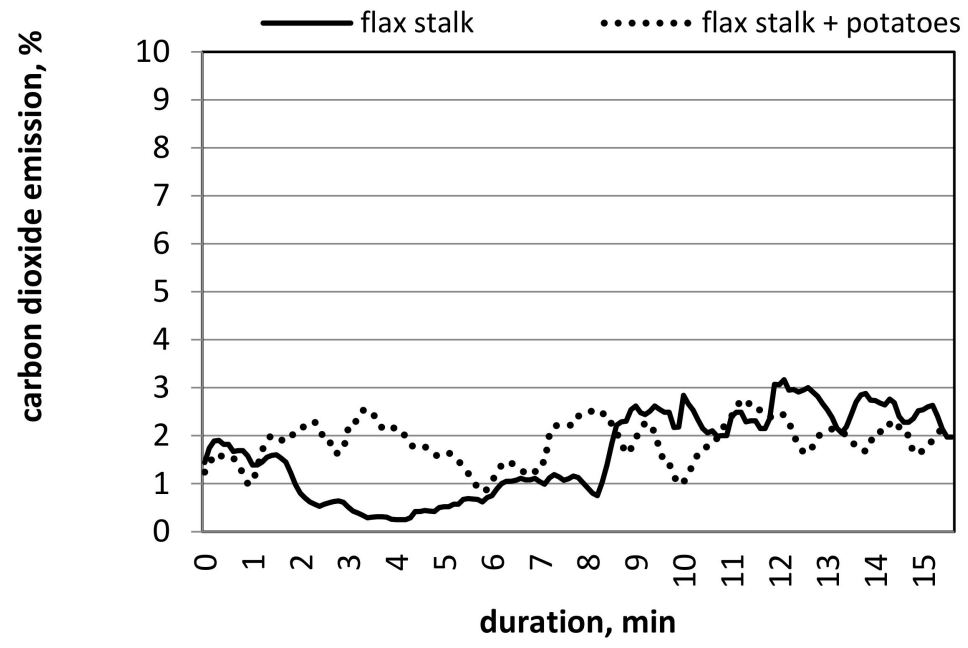

Figure 11. Duration of the carbon dioxide emissions of the pellet variants tested during the combustion test.

The results of the combustion tests show that the combustion of pellets with the addition of potatoes resulted in a higher concentration of carbon monoxide emissions, especially in the initial phase of combustion. The emission concentrations of other measured gases (i.e., $\mathrm{NO}_{\mathrm{X}}$ and carbon dioxide) were different in both variants. Compared with the results of other researchers, lower $\mathrm{NO}_{\mathrm{x}}$ values were found [22]. However, on closer comparison, only $\mathrm{NO}$ is included in the $\mathrm{NO}_{\mathrm{x}}$ emissions. In addition, the authors' results are converted to an oxygen content of $10 \%$.

When testing biofuels from hemp, which is closest in type to flax stalks, other authors have presented these research results $[21,25]$. When converted to a reference oxygen content of $10 \%$ according to the stated average value, the carbon monoxide concentration ranged from 3240.8 to $10,261.3 \mathrm{mg} / \mathrm{m}^{3} \mathrm{~N}$, the $\mathrm{NO}_{\mathrm{x}}$ concentration ranged from 554.3 to $682.5 \mathrm{mg} / \mathrm{m}^{3} \mathrm{~N}$, and the carbon dioxide concentration varied from $3.1 \%$ to $5.0 \%$. Compared to these values, in the case of pellets with the addition of potatoes, lower emission concentrations of all of the monitored elements were achieved. In the variant without potatoes, lower emission values were also achieved, except for the concentration of carbon monoxide in the initial combustion phase. Comparable emission values of the monitored substances were also achieved during the combustion of post-harvest tobacco residues: the concentration of carbon monoxide was $8243.3 \mathrm{mg} / \mathrm{m}^{3}{ }_{\mathrm{N}}$ and the concentration of $\mathrm{NO}_{\mathrm{x}}$ was $224.3 \mathrm{mg} / \mathrm{m}^{3}{ }_{\mathrm{N}}$ [29].

The limit values of the emitted pollutants from fuel-burning devices are regulated by the norms of emitted pollutants from fuel-burning devices, as outlined by the Ministry of Environment of the 
Czech Republic (Act No. 201/2012, Decree No. 415/2012) [43]. According to this valid legislation, appliances (sources of pollution) are assessed in terms of emissions, not fuel. Herein, this was assessed in terms of the analytical and mechanical properties that flax pellets with the addition of potatoes meet. The emission limit used by the combustion plant was exceeded during the combustion tests. From the aforementioned legislation, the carbon monoxide emission limit for appliances up to $65 \mathrm{~kW}$ is $5000 \mathrm{mg} / \mathrm{m}^{3} \mathrm{~N}$ (manual application) and $3000 \mathrm{mg} / \mathrm{m}^{3} \mathrm{~N}$ (automatic application). The $\mathrm{NO}_{\mathrm{x}}$ emission limit for this type of appliance is set to $200 \mathrm{mg} / \mathrm{m}^{3} \mathrm{~N}$. According to the legislation, the stated limits are related to a reference oxygen content of $13 \%$. Due to the unsuitable type of appliance for the tested type of fuel, further research will be focused on finding a suitable design solution for a small appliance and testing the quality of the combustion and co-combustion in higher output boilers.

\section{Conclusions}

In the described research, the possibility of using potatoes as an additive in the production of heating pellets from flax stalks was tested and the properties were determined. Based on the results obtained, it is clear that potatoes can be used as a binder in the $10 \%$ fraction tested. The tested variant with an addition of $10 \%$ of potatoes was compared on different criteria to the control variant without potatoes. The addition of potatoes mainly improved the mechanical properties and the burning stability of the pellets.

As part of the verification experiments, the specific energy consumption for the preparation of raw material and the production of pellets on an MGL 200 pelletizing line was determined. In this respect, both variants turned out to be similar. The consumption of specific energy to produce the pellets was $0.305 \mathrm{MJ} / \mathrm{kg}$ (potato-free variant) and $0.286 \mathrm{MJ} / \mathrm{kg}$ (variant with potatoes).

The largest difference between the pellet variants was recorded in terms of mechanical properties. A positive effect of the addition of potatoes was indicated by an increase in specific weight $\left(599.2 \mathrm{~kg} / \mathrm{m}^{3}\right.$ for the potato-free variant and $1092.3 \mathrm{~kg} / \mathrm{m}^{3}$ for the variant with potatoes) and a significant increase in mechanical durability ( $4.39 \%$ for the potato-free variant and $0.71 \%$ for the variant with potatoes).

Analytical properties of the pellets produced were also investigated. The pellets with potatoes had a slight increase in moisture content and, therefore, a slightly lower low heating value. Due to the addition of potatoes, the content of silicon, ash, and zinc also increased slightly. However, this difference was small and insignificant in terms of properties.

Carbon monoxide, $\mathrm{NO}_{x}$, and carbon dioxide emissions were measured during the combustion tests. The values were converted to a reference oxygen content of $10 \%$. The largest difference in the measured emission concentrations found in carbon monoxide was in favor of the variant with potatoes $\left(13,082 \mathrm{mg} / \mathrm{m}^{3} \mathrm{~N}\right.$ for the potato-free variant and $5186 \mathrm{mg} / \mathrm{m}^{3}{ }_{\mathrm{N}}$ for the variant with potatoes). This was especially the case in the initial phase of combustion. In other cases, the results obtained were similar. Moreover, similar or lower values were obtained in comparison to the values reported in the literature.

These results show that potatoes can be used as a binder for heating pellets. In the case of the verified variant with the addition of $10 \%$ of potatoes to pellets produced from oil flax stalks, no negative effect on any of the examined parameters was observed. The addition of potatoes had a positive effect mainly on the increase in specific weight and mechanical durability. A positive effect was also recorded in terms of reducing carbon monoxide emissions.

Further research will be focused on finding a suitable design solution for a small appliance and on testing the quality of combustion and co-combustion in higher output boilers. It is also possible to investigate the addition of other additives, coming primarily from agricultural residual raw materials.

This research has verified the possibility of using flax stalks for energy purposes with the addition of potatoes. The proposed solution is particularly advantageous for flax and potato growers. Flax stalks that are not economically beneficial to sell can be used to produce heating pellets that meet the required standards. The proposed solution will also allow for efficient use of overproduced potatoes or their unused stocks. 
Author Contributions: Conceptualization, J.S. and A.J.; methodology, J.S.; investigation, J.S. and A.J.; resources, J.S.; data curation, J.S. and A.J.; writing—original draft preparation, J.S. and A.J.; writing-review and editing, J.S. and A.J.; supervision, J.S. and A.J.; funding acquisition, J.S. and A.J. All authors have read and agreed to the published version of the manuscript.

Funding: This proceeding originated within the project of the longtime development of the Research Institute of Agricultural Engineering p. r. i. No. RO0618 and the project of the Ministry of Agriculture of the Czech Republic No. QK21010151.

Conflicts of Interest: The authors declare no conflict of interest.

\section{References}

1. Souček, J.; Jasinskas, A.; Sillinger, F.; Szalay, K. Determination of Mechanical and Energetic Properties of Reed Canary Grass Pellets Production. Acta Univ. Agric. Silvic. Mendel. Brun. 2019, 67, 757-762. [CrossRef]

2. Blazej, D.; Souček, J. Comparsion of solid biofuel types from linseed stems. In Engineering for Rural Development, Proceedings of the 11th Inernational Scientific Conference on Engineering for Rural Development, Jelgava, Latvia, 24-25 May 2012; Latvia University of Agriculture: Jelgava, Latvia, 2012; Volume 11, pp. 434-437.

3. Plíštil, D.; Brožek, M.; Malat'ák, J.; Roy, A.; Hutla, P. Mechanical characteristics of standard fuel briquettes on biomass basis. Res. Agric. Eng. 2005, 51, 66-72. [CrossRef]

4. Souček, J. Assessment of linseed harvest efficiency. In Proceedings of the 6th International Conference on Trends in Agricultural Engineering, Prague, Czech Republic, 7-9 September 2016.

5. Agüero, Á.; Lascano, D.; Garcia-Sanoguera, D.; Fenollar, O.; Torres-Giner, S. Valorization of Linen Processing By-Products for the Development of Injection-Molded Green Composite Pieces of Polylactide with Improved Performance. Sustainability 2020, 12, 652. [CrossRef]

6. Frydrych, M.; Hýsek, Š.; Fridrichová, L.; Le Van, S.; Herclík, M.; Pechočiaková, M.; Le Chi, H.; Louda, P. Impact of Flax and Basalt Fibre Reinforcement on Selected Properties of Geopolymer Composites. Sustainability 2020, 12, 118. [CrossRef]

7. Blažej, D. Utilization of stalk materials and their mixtures with wooden shavings for briquettes production. In Proceedings of the 6th International Conference on Trends in Agricultural Engineering, Prague, Czech Republic, 3-6 September 2013; pp. 86-88.

8. Komlajeva, L.; Adamovics, A. Evaluation of flax (linumusitatissimum 1.) quality parameters for bioenergy production. In Engineering for Rural Development, Proceedings of the 11th Inernational Scientific Conference on Engineering for Rural Development, Jelgava, Latvia, 24-25 May 2012; Latvia University of Agriculture: Jelgava, Latvia, 2012; Volume 11, pp. 490-495.

9. Obidzinski, S.; Dolzynska, M.; Lewicka, S. Analysis of physical properties of dietary fiber from apple waste. In Proceedings of the IX International Scientific Symposium on Farm Machinery and Processes Management in Sustainable Agriculture, Lublin, Poland, 22-24 November 2017; pp. 272-277.

10. Jaganathan, V.M.; Varunkumar, S. A novel self-sustained single step process for synthesizing activated char from ligno-cellulosic biomass. Fuel Process. Technol. 2020, 208, 106516. [CrossRef]

11. Souček, J.; Kocánová, V.; Novák, M. Parametres of energy crop biomass handling. Res. Agric. Eng. 2007, 53, 161-165. [CrossRef]

12. Martinele, I.; Paiva, P.C.; Lopes, F.C.F.; Pereira, J.D.; Ferreira, L.R. Digestibility of pelleted rations containing diverse potato flour and urea. Cienc. Rural 2015, 45, 2063-2068. [CrossRef]

13. Obidzinski, S.; Dolzynska, M.; Stasieluk, W. Production of fuel pellets from a mixture of sawdust and rye bran. In Proceedings of the 2nd International Conference on the Sustainable Energy and Environmental Development (SEED), Krakow, Poland, 14-17 November 2017.

14. Szalay, D.K.; Hárs, T.; Klupács, H. Copper-An important element influencing wheat quality. Cereal Res. Commun. 2006, 34, 77-80.

15. Alrefai, R.; Alrefai, A.M.; Benyounis, K.Y.; Stokes, J. An Evaluation of the Effects of the Potato Starch on the Biogas Produced from the Anaerobic Digestion of Potato Wastes. Energies 2020, 13, 2399. [CrossRef]

16. Achinas, S.; Li, Y.; Achinas, V.; Euverink, G.J.W. Biogas Potential from the Anaerobic Digestion of Potato Peels: Process Performance and Kinetics Evaluation. Energies 2019, 12, 2311. [CrossRef]

17. Javed, A.; Ahmad, A.; Tahir, A.; Shabbir, U.; Nouman, M.; Hameed, A. Biogas Potato peel wasteIts nutraceutical, industrial and biotechnological applacations. Aims Agric. Food 2019, 4, 807-823. [CrossRef] 
18. Obidzinski, S. Pelletization of biomass waste with potato pulp content. Int. Agrophysics 2014, $28,85-91$. [CrossRef]

19. Obidzinski, S. Analysis of usability of potato pulp as solid fuel. Fuel Process. Technol. 2012, 94, 67-74. [CrossRef]

20. Obidzinski, S. Utilization of Post-Production Waste of Potato Pulp and Buckwheat Hulls in the Form of Pellets. Polisch J. Environ. Stud. 2014, 23, 1391-1395.

21. Obidzinski, S.; Dolzynska, M.; Kowczyk-Sadowy, M.; Piekut, J.; Czerniawski, S.; Sobczak, P. Investigation of pelleting proces of hemp waste with potato pulp. Carpathian J. Food Sci. Technol. Spec. Issue 2018, 10, $53-64$.

22. Vitoussia, T.; Leyssens, G.; Trouve, G.; Brillard, A.; Kemajou, A.; Njeugna, E.; Brilhac, J.F. Analysis of the combustion of pellets made with three Cameroonian biomass in a domestic pellet stove. Fuel 2020, 276, 118105. [CrossRef]

23. Kraszkiewicz, A.; Przywara, A.; Anifantis, A.S. Impact of Ignition Technique on Pollutants Emission during the Combustion of Selected Solid Biofuels. Energies 2020, 13, 2664. [CrossRef]

24. Mock, C.; Park, H.; Ryu, C.; Manovic, V.; Choi, S.C. Particle temperature and flue gas emission of a burning single pellet in air and oxy-fuel combustion. Combust. Flame 2020, 213, 156-171. [CrossRef]

25. Jasinskas, A.; Streikus, D.; Vonzodas, T. Fibrous hemp (Felina 32, USO 31, Finola) and fibrous nettle processing and usage of pressed biofuel for energy purposes. Renew. Energy 2019, 149, 11-21. [CrossRef]

26. Jasinskas, A.; Streikus, D.; Sarauskis, E.; Palsauskas, M.; Venslauskas, K. Energy Evaluation and Greenhouse Gas Emissions of Reed Plant Pelletizing and Utilization as Solid Biofuel. Energies 2019, 13, 1516. [CrossRef]

27. Andert, D. Experience from Combustion of Alternative Pellets. Agritechnol. Sci. 2010, 4, 86-88. Available online: http://www.agritech.cz/clanky/2010-1-9.pdf (accessed on 19 June 2020).

28. Malat'ák, J.; Gendek, A.; Aniszewska, M.; Velebil, J. Emissions from combustion of renewable solid biofuels from coniferous tree cones. Fuel 2020, 276. [CrossRef]

29. Obidziński, S.; Puchlik, M.; Dołżyńska, M. Pelletization of Post-Harvest Tobacco Waste and Investigation of Flue Gas Emissions from Pellet Combustion. Energies 2020, 13, 6002. [CrossRef]

30. Cutting Screw Driver 650, 750, 850, 950, 1000. Available online: http://www.kovonovak.cz/rezaci-srotovnikrs-650 (accessed on 15 June 2020).

31. Adela-Potatoes with Taste. Available online: http://www.sadba.cz/adela.htm (accessed on 15 June 2020).

32. SM 300 Shear Mill. Available online: https://www.retsch.cz/cz/produkty/mleti/strizne-mlyny/sm-300/funkcea-charakteristiky (accessed on 18 June 2020).

33. Professional Lines for the Production of Pellets-Kovo Novak. Available online: http://www.kovonovak.cz/ cs/content/granulacni-linky-vyroba-pelet (accessed on 10 July 2020).

34. Kern Scales. Available online: https://vahy-kern.cz/produkty/kern-prumyslove-vahy/stolni-vahy/fkb-astolni-vahy (accessed on 10 July 2020).

35. ISO. Solid Biofuels—Determination of Bulk Density; ISO 17828:2015; ISO Copyright Office: Geneva, Switzerland, 2015.

36. ISO. Solid Biofuels-Determination of Mechanical Durability of Pellets and Briquettes-Part 1: Pellets; ISO 17831-1:2015; CEN ISO Copyright Office: Geneva, Switzerland, 2015.

37. ISO. Solid Biofuels_Determination of Moisture Content_Oven Dry Method_Part 3: Moisture in General Analysis Sample; ISO 18134-3:2015; ISO Copyright Office: Geneva, Switzerland, 2015.

38. ISO. Solid Biofuels-Determination of Calorific Value; ISO 18125:2018; CEN: Brussels, Belgium, 2018.

39. ISO. Determination of Minor Elements-As, Cd, Co, Cr, Cu, Hg, Mn, Mo, Ni, Pb, Sb, V and Zn; EN 15297:2011; ISO Copyright Office: Geneva, Switzerland, 2011.

40. ISO. Solid Biofuels-Determination of Total Content of Carbon, Hydrogen and Nitrogen; ISO 16948:2015; ISO Copyright Office: Geneva, Switzerland, 2015.

41. ISO. Solid Biofuels_Fuel Specifications and Classes_Part 6: Graded Non-Woody Pellets; ISO 17225-6:2014; ISO Copyright Office: Geneva, Switzerland, 2014.

42. Greinert, A.; Mrówczyńska, M.; Grech, R.; Szefner, W. The Use of Plant Biomass Pellets for Energy Production by Combustion in Dedicated Furnaces. Energies 2020, 13, 463. [CrossRef] 
43. Stasiak, M.; Molenda, M.; Bańda, M.; Horabik, J.; Wiącek, J.; Parafiniuk, P.; Wajs, J.; Gancarz, M.; Gondek, E.; Lisowski, A.; et al. Friction and Shear Properties of Pine Biomass and Pellets. Materials 2020, 13, 3567. [CrossRef]

Publisher's Note: MDPI stays neutral with regard to jurisdictional claims in published maps and institutional affiliations.

(C) 2020 by the authors. Licensee MDPI, Basel, Switzerland. This article is an open access article distributed under the terms and conditions of the Creative Commons Attribution (CC BY) license (http://creativecommons.org/licenses/by/4.0/). 